\title{
Impact of Urbanization on Land Surface Temperature - A Case Study of Kolkata New Town
}

\author{
SK Akher ${ }^{1}$, Dr. Subhra Chattopadhyay ${ }^{2}$ \\ ${ }^{1}$ Senior Research Fellow, Department of Geography, Lady Brabourne College \\ ${ }^{2}$ Associate Professor, Department of Geography, Lady Brabourne College
}

\begin{abstract}
Land Surface Temperature depends on the nature of land surface. Water bodies, green fields remain cooler than bare ground and built-up area. Kolkata New Town is emerging in agricultural area through filling of big water bodies and converting cultivated lands into built up area. This study aims to analyse the changes in land surface temperature with advent of the town. It is found that the land surface temperature is increasing sharply. The mean temperature of the area was $22.8^{\circ} \mathrm{C}$ in 1996 which became $24.9^{\circ} \mathrm{C}$ in 2004 and $26.4^{\circ} \mathrm{C}$ in 2014. Spatial variation was sharp during early stage of project i.e. 1996-2004. Besides The relation of built-up (NDBI) and LST is found positively co-related with a r value of 0.76 in 2004 and 0.73 in 2014 and the relation with vegetation (NDVI) is negatively related and the $r$ value is -.0.35 in both the years of 2004 and 2014. Several patches of heat zones are now being popped up these zones have been identified on the map of Kolkata New Town. The study suggests toconsider the possible micro-climatic changes in town planning for the sustainable development.
\end{abstract}

Keywords: Land surface temperature (LST), Normalized differential built-up index (NDBI), Normalized differential vegetation index (NDVI), Temperature Profile, Urbanization.

\section{INTRODUCTION}

Land Surface Temperature (LST) means skin temperature of the surface. (Latif, 2014) LST depends on insolation as well as nature of the surface or object material. Generally water bodies, vegetative area as well as wet soil are cooler than bare soil, sand, metal, built up area. So there is a positive relation between LST with urbanization.

Kolkata New Town is a planned project of the Govt. of West Bengal which is initiated in 1999. The Development of Housing, Govt. of West Bengal constituted a Technical Committee in May 1993 for preparation of a preliminary report of the New Town planning. In 1994 CMDA prepared a concept Plan for development of Kolkata New Town. The master plan was made by Indian Institute of Technology in 1996. In 1999 the Master Land use Plan and detail sector plan for township was prepared and West Bengal Housing Infrastructure Development Corporation Limited (WB-HIDCO) started implementing the plan (Chakrabarty et. al, 2015). The Town is now under development.

The study aims to estimate how far the expansion of the new town affects the land surface temperature of this area. For this purpose LST is compare for the year of 1996, 2004, 2014.

\section{STUDY AREA}

The Kolkata New Town area which is taken by the New Town development authority for the planning is considered for the study. It is demarcated by HIDCO. Total area is $102 \mathrm{sq} . \mathrm{km}$ from which $60 \mathrm{sq} . \mathrm{km}$ is now under planning. 


\section{Map no. -1 : Location Map Location of Kolkata New Town}

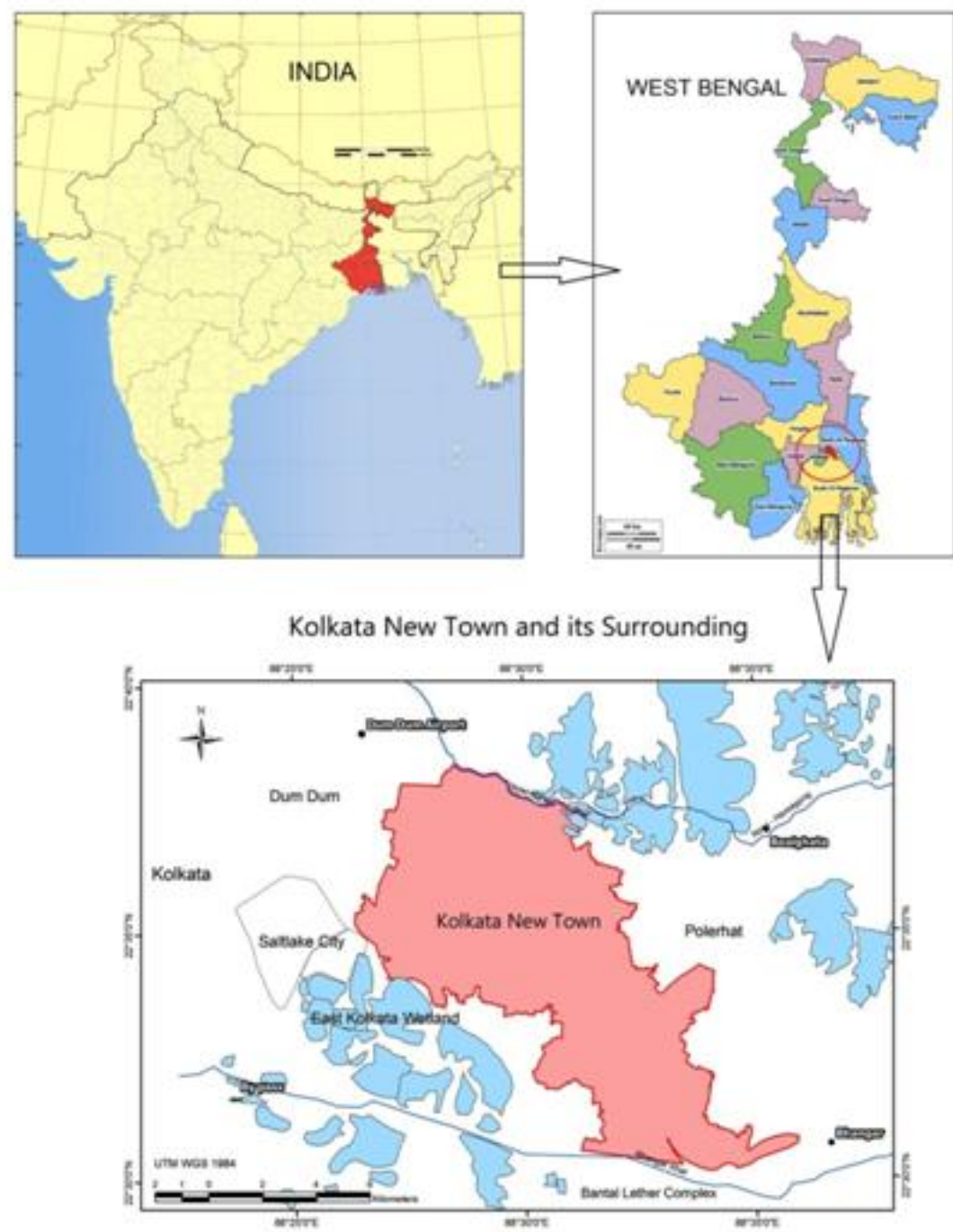

\section{MATERIAL AND METHODS}

For this study following steps have been followed.

\section{i) Material}

Landsat TM satellite images of 1996, 2004, 2011 and Landsat 8 images of 2014 are downloaded from 'Earth Explorer' website of United States Geological Survey (USGS). The Landsat TM has a Thermal Infra-Red (TIR) band (i.e. Band 6) and Landsat 8 has two Thermal Infra-Red (TIR) band (i.e. Band 10 \& 11). Both the images are processed in ArcGIS 10.2 to retrieve the Land Surface Temperature. The Landsat satellite image details are given below (Table-1, 2, 3).

Table- 1: Detail of Landsat data used

\begin{tabular}{|l|l|l|l|l|l|}
\hline Sl. No & Satellite & Sensor & Date of acquisition & Time (IST) & Sun elevation \\
\hline 1 & Landsat 5 & TM & $30 / 11 / 1996$ & $9: 23 \mathrm{am}$ & $36.47^{\circ}$ \\
\hline 2 & Landsat 5 & TM & $20 / 11 / 2004$ & $9: 46 \mathrm{am}$ & $41.37^{\circ}$ \\
\hline 3 & Landsat 8 & OLI \& TIRs & $16 / 11 / 2014$ & $10: 02 \mathrm{am}$ & $45.35^{\circ}$ \\
\hline
\end{tabular}

Table - 2: Band detail of Landsat TM5

\begin{tabular}{|l|l|l|l|l|}
\hline Sl. No & Band & Type & Spectral range $(\mu \mathrm{m})$ & spatial resolution $(\mathrm{m})$ \\
\hline 1 & 4 & Red & $0.76-0.90$ & 30 \\
\hline 2 & 5 & NIR & $1.55-1.75$ & 30 \\
\hline 3 & 6 & TIR & $10.40-12.50$ & $120(30$ resampled $)$ \\
\hline
\end{tabular}


Table - 3: Band detail of Landsat 8

\begin{tabular}{|l|l|l|l|l|}
\hline Sl. No & Band & type & Spectral range $(\mu \mathrm{m})$ & spatial resolution $(\mathrm{m})$ \\
\hline 1 & 4 & Red & $0.64-0.67$ & 30 \\
\hline 2 & 5 & NIR & $0.85-0.88$ & 30 \\
\hline 3 & 6 & SWIR & $1.57-1.65$ & 30 \\
\hline 4 & 7 & SWIR & $2.11-2.29$ & 30 \\
\hline 5 & 10 & TIR & $10.60-11.19$ & $100(30$ resampled $)$ \\
\hline 6 & 11 & TIR & $11.50-12.51$ & $100(30$ resampled $)$ \\
\hline
\end{tabular}

ii) Methodology:

A. The LST will be retrieved depends on the type of Satellite sensor.

\section{a. Retrieval of LST from Landsat TM}

Step1. Using following formula, Spectral Radiance (L $\lambda$ ) has been calculated through Conversion of the Digital Number (DN)

$\mathrm{L}_{\lambda}=\left(\left(\mathrm{LMAX}_{\lambda}-\mathrm{LMIN}_{\lambda}\right) /\left(\mathrm{QCAL}_{\mathrm{MAX}}-\mathrm{QCAL} \mathrm{MIN}_{\mathrm{N}}\right)\right) *\left(\mathrm{QCAL}-\mathrm{QCAL} \mathrm{MIN}_{\mathrm{N}}\right)+\mathrm{LMIN}_{\lambda}$

where:

$\mathrm{L}_{\lambda}=$ Spectral Radiance at the sensor's aperture in watts/(sq.m)

$\mathrm{LMAX}_{\lambda}=$ the spectral radiance that is scaled to $\mathrm{QCAL}_{\mathrm{MAX}}$ in watts/( sq. m)

$\mathrm{QCAL}_{\mathrm{MIN}}=$ the minimum quantized calibrated pixel value (corresponding to $\mathrm{LMIN}_{\lambda}$ ) in DN

$\mathrm{QCAL}_{\mathrm{MAX}}=$ the maximum quantized calibrated pixel value (corresponding to $\mathrm{LMAX}_{\lambda}$ ) in DN

Step2. Next, Spectral Radiance has been converted to Temperature in Kelvin by following formula.

$$
T=\frac{K 2}{\ln \left(\frac{K 1}{L_{\lambda}}+1\right)}
$$

Where:

$\mathrm{T}=$ Effective at-satellite temperature in Kelvin

$\mathrm{K} 2$ = Calibration constant 2 from metadata

$\mathrm{K} 1$ = Calibration constant 1 from metadata

$\mathrm{L}_{\lambda}=$ Spectral radiance in watts/(sq. $\mathrm{m}$ )

Step 3. Land Surface Temperature (LST) has been calculated using following formula

$\mathrm{TK}=\mathrm{T} /(\varepsilon-4)$

Where:

$\mathrm{TK}=$ Temperature in $0 \mathrm{C}$

$\mathrm{T}=$ Temperature in Kelvin

\section{b. Estimation of LST from Landsat 8}

Step1. Conversion of the Digital Number (DN) to Spectral Radiance (L)

$\mathrm{L}_{\lambda}=\mathrm{ML} \mathrm{Qcal}+\mathrm{AL}$

Where:

$\mathrm{L}_{\lambda}=$ TOA spectral radiance (watts/steradian/ sq.m),

$\mathrm{ML}=$ Band-specific multiplicative rescaling factor from the metadata,

$\mathrm{AL}=\mathrm{B}$ and-specific additive rescaling factor from the metadata,

Qcal =Quantized and calibrated standard product pixel value (DN value),

Step2. Next, Spectral Radiance has been converted to Temperature in Kelvin by following formula.

$$
T=\frac{K 2}{\ln \left(\frac{K 1}{L_{\lambda}}+1\right)}
$$

Where:

$\mathrm{T}=$ Effective at-satellite temperature in Kelvin

$\mathrm{K} 2$ = Calibration constant 2 from metadata

$\mathrm{K} 1$ = Calibration constant 1 from metadata

$\mathrm{L}_{\lambda}=$ Spectral radiance in watts/(sq. $\mathrm{m}$ ) 
Step3. Land surface emissivity calculation

Land surface emissivity (e) has been calculated using following equation:

$\mathrm{e}=0.004 \mathrm{PV}+0.986$

where,

$\mathrm{PV}=$ Proportion of vegetation, which is calculated by the following formula

$\mathrm{PV}=\left(\mathrm{NDVI}-\mathrm{NDVI}_{\mathrm{Min}} / \mathrm{NDVI}_{\mathrm{Max}}-\mathrm{NDVI}_{\mathrm{Min}}\right) 2$

where,

The NDVI is calculated from the equation

$\mathrm{NDVI}=(\mathrm{NIR}-\mathrm{Red}) /(\mathrm{NIR}+\mathrm{Red})$

Step4. Land surface temperature (LST) estimation

The land surface temperature (LST) has been estimated using the single window algorithm.

$\mathrm{LST}=\mathrm{BT} / 1+\mathrm{w} *(\mathrm{BT} / \mathrm{P}) * \mathrm{In}(\mathrm{e})$

where

LST = Land surface temperature (in Kelvin),

BT = At-satellite brightness temperature (in Kelvin),

$\mathrm{W}=$ wavelength of emitted radiance, $(11.5 \mu \mathrm{m})$,

$\mathrm{P}=\mathrm{h} * \mathrm{c} / \mathrm{s},\left(1.438 * 10^{\wedge}-2 \mathrm{~m} \mathrm{~K}\right)$

where

$\mathrm{h}=$ Planck's constant $\left(6.626 * 10^{\wedge}-34 \mathrm{Js}\right)$,

$\mathrm{s}=$ Boltzmann constant $\left(1.38 * 10^{\wedge}-23 \mathrm{~J} / \mathrm{K}\right)$,

$\mathrm{c}=$ Velocity of light $\left(2.998 * 10^{\wedge} 8 \mathrm{~m} / \mathrm{s}\right)$

Calculating the LST for both the Band 10 and 11 in kelvin and 273.15 is subtracted from the both raster to get the temperature in 0C. Finally average of the two bands temperature is taken for the study.

B. Normalized Differential Vegetation Index (NDVI) Normalized Difference Built up Index (NDBI) which has been used for identifying the built up area and Normalized Differential Built up Index (NDBI) are estimated for the year 2004 and 2014 using the following formulae (Liu \& Zhang, 2011).

NDVI $=($ NIR - Red $) /($ NIR + Red $)$

Where,

NDVI $=$ Normalized Differential Vegetation Index

NIR $=$ Near Infra-Red Band, Red= Red Band

$\mathrm{NDBI}=(\mathrm{MIR}-\mathrm{Red}) /(\mathrm{MIR}+\mathrm{Red})$

Where,

NDBI $=$ Normalized Differential Built up Index

MIR= Mid Infra-Red Band, Red= Red Band

C. The correlation coefficient between LST and NDVI and LST and NDBI is done for both the years.

D. Three profiles are drawn to show the distribution of LST of 2014 in different area.

\section{i) spatial and temporal changes of LST:}

\section{RESULTS AND DISCUSSION}

LST Maps which have been prepared in this study have shown spatial as well as temporal changes in LST of Kolkata New Town area.

In 1996 the LST maximum and minimum were $26.6^{\circ} \mathrm{C}$ and $19.9^{\circ} \mathrm{C}$ respectively at the south-east part, thus variation is $6.7 \mathrm{C}$. The mean LST was $22.8^{\circ} \mathrm{C}$ with a standard deviation of $0.8^{\circ} \mathrm{C}$. The warmer area was the south eastern part of New Town project area in the then time (map no: 2). In 1996 the area was agricultural field. The area was kept as seasonal fallow during image acquisition time for what it is found warmer. In 2004 it is found that the warmer area was shifted to north-west and western side where the wetland like Chandibari Beel, Ghuni beel once existed and now filled up marked as built-up area. The maximum and minimum LST was $28.3^{\circ} \mathrm{C}$ and $22.6^{\circ} \mathrm{C}$ respectively in this pocket. Hence the spatial range of temperature is about $5 \mathrm{c}$. The mean LST increased from $22.8^{\circ} \mathrm{C}$ to $24.9^{\circ} \mathrm{C}$ where the standard deviation remain same i.e. $0.8^{\circ} \mathrm{C}$. The LST further increased in 2014. The maximum and minimum LST changed to $29.7^{\circ} \mathrm{C}$ and $24^{\circ} \mathrm{C}$. The mean LST has increased from $24^{\circ} \mathrm{C}$ to $26.4^{\circ} \mathrm{C}$ and the standard deviation has increased to $1^{\circ} \mathrm{C}$ (table -4 ). The most of the warm area 
Impact Of Urbanization On Land Surface Temperature - A Case Study Of Kolkata New Town

retains at the same position in 2004 but several new patches of warmer zones have raised where the new built up areas are emerging.

Table - 4: Changing LST in Kolkata New Town

\begin{tabular}{|l|l|l|l|l|l|}
\hline \multirow{2}{*}{ Year } & \multicolumn{5}{|l|}{ Land Surface Temperature (LST) in ${ }^{\circ} \mathrm{C}$} \\
\cline { 2 - 6 } & Maximum & Minimum & Range & Mean & Standard Deviation \\
\hline 1996 & 26.6 & 19.9 & 6.7 & 22.8 & 0.8 \\
\hline 2004 & 28.3 & 22.6 & 5.7 & 24.9 & 0.8 \\
\hline 2014 & 29.7 & 24 & 5.7 & 26.4 & 1 \\
\hline
\end{tabular}

Map No. - 2: LST map, Nov, 1996

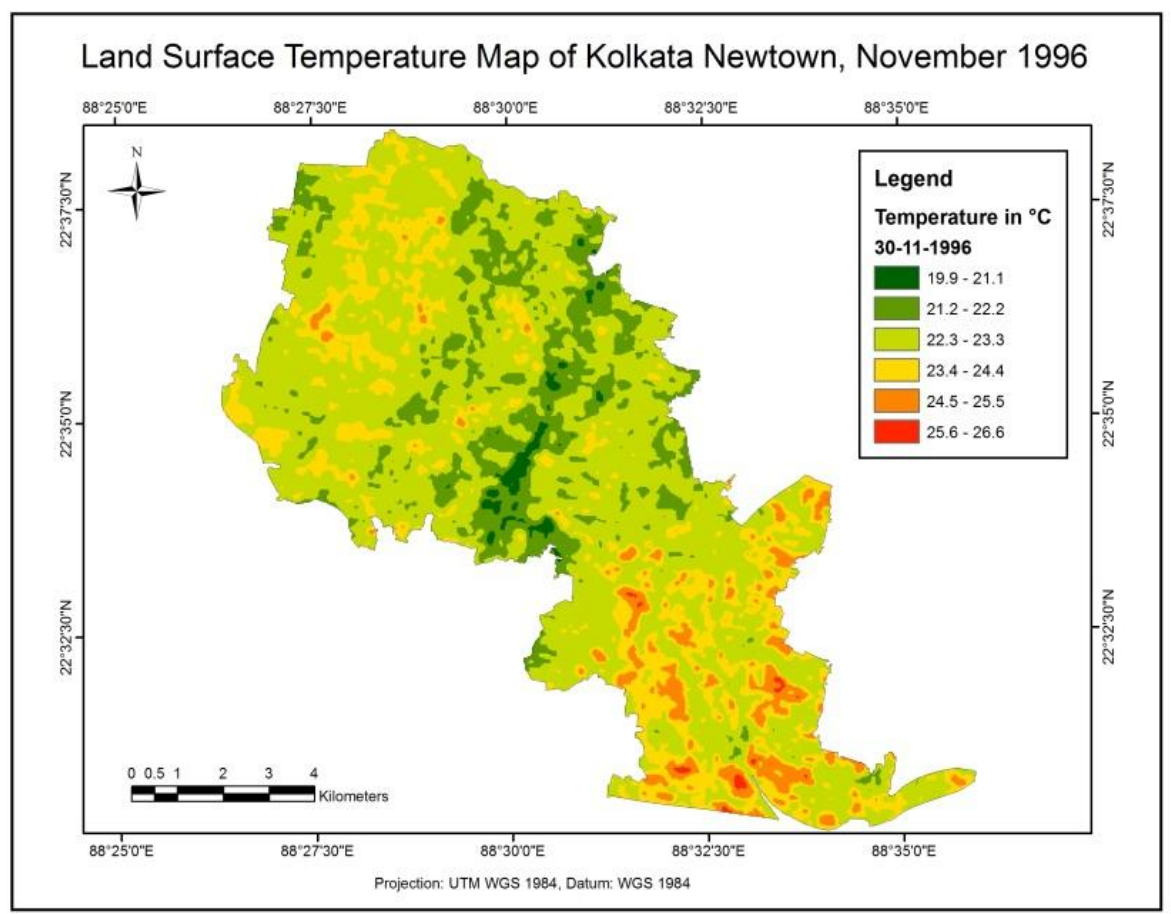

Map No. - 3: LST map, Nov, 2004

Land Surface Temperature Map of Kolkata Newtown, November 2004

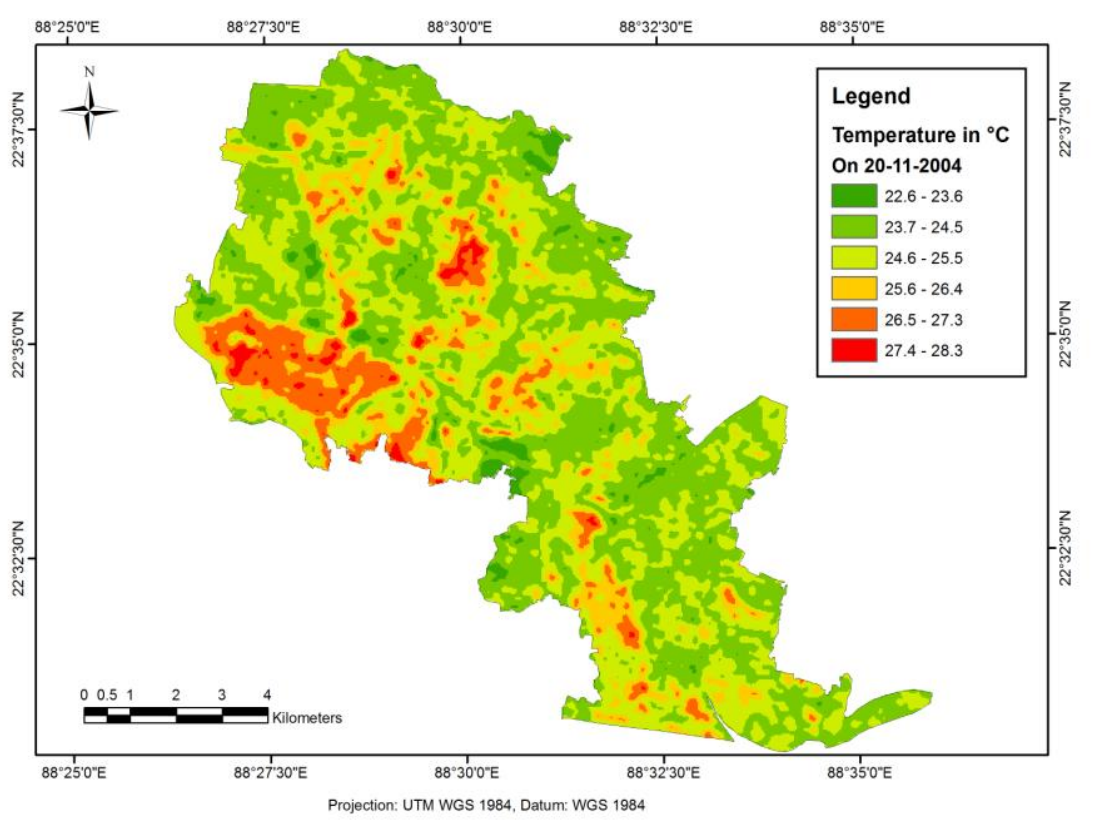




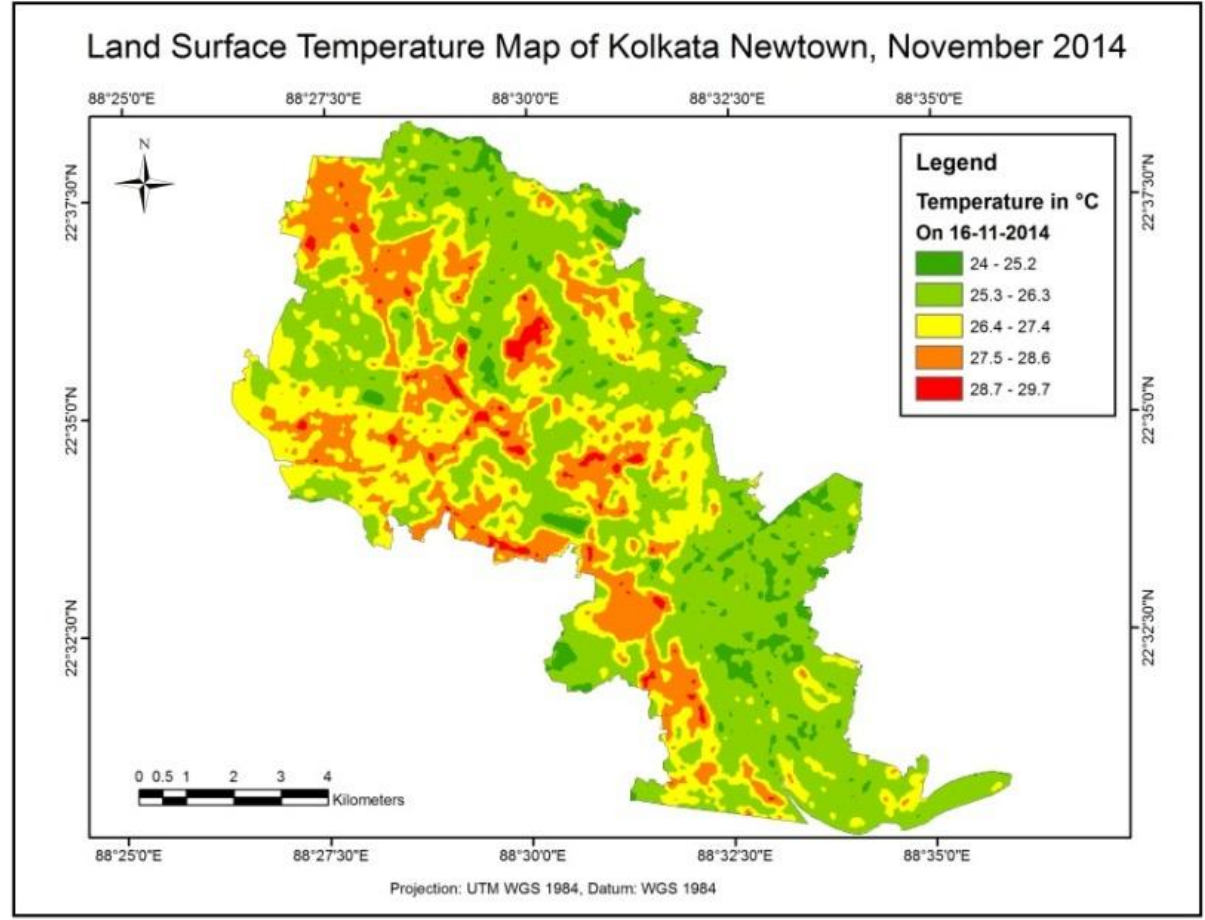

Map No. - 3: LST map, Nov, 2014

Temperature map clearly shows that LST has increased. These are mainly at built up area and urban fallow land which is going to be built up.

\section{ii) Relation among LST, NDVI and NDBI:}

Relationship between LST and normalized difference built-up index (NDBI), is strongly positive ( $\mathrm{r}=0.76$ in $2004 \& \mathrm{r}=0.73$ in 2014). The LST and Normalized Vegetation index (NDVI) have a weak but negative corelation( $\mathrm{r}=-0.35$ for both $2004 \& 2014)($ Table-5, 6)

Fig- 1: Correlation between LST \& NDBI, 2004

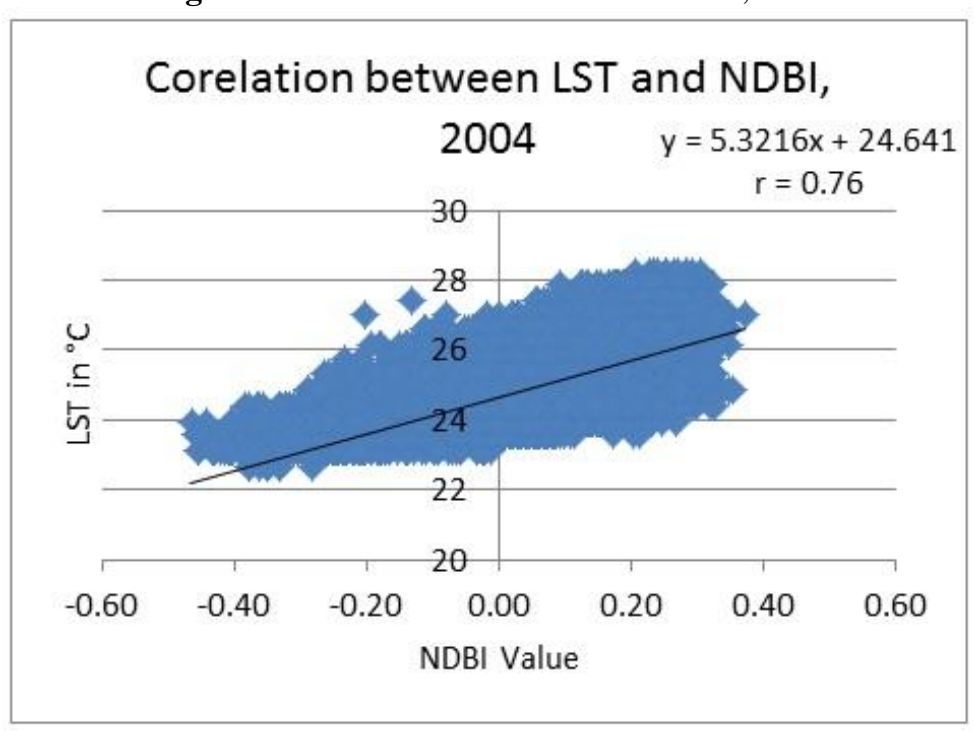

Table - 5: Co-relation (r) among NDVI, NDBI and LST, 2004

\begin{tabular}{|l|l|l|l|}
\hline & NDVI & NDBI & LST \\
\hline NDVI & 1 & & \\
\hline NDBI & -0.31 & 1 & \\
\hline LST & -0.35 & 0.76 & 1 \\
\hline
\end{tabular}


Table - 6: Co-relation (r) among NDVI, NDBI and LST, 2014

\begin{tabular}{|l|l|l|l|}
\hline & NDVI & NDBI & LST \\
\hline NDVI & 1 & & \\
\hline NDBI & -0.66 & 1 & \\
\hline LST & -0.35 & 0.73 & 1 \\
\hline
\end{tabular}

LST has increased in the area which is mainly built up area. It produces patchy temperature zones.

Changes in LST is maximum during the period of 1996-2004 i.e the main period of land acquisition and land filling specially large water bodies (which are locally known as Bheri ). (map no: 4).

Map No. - 4: Change of LST from 1996 to 2004

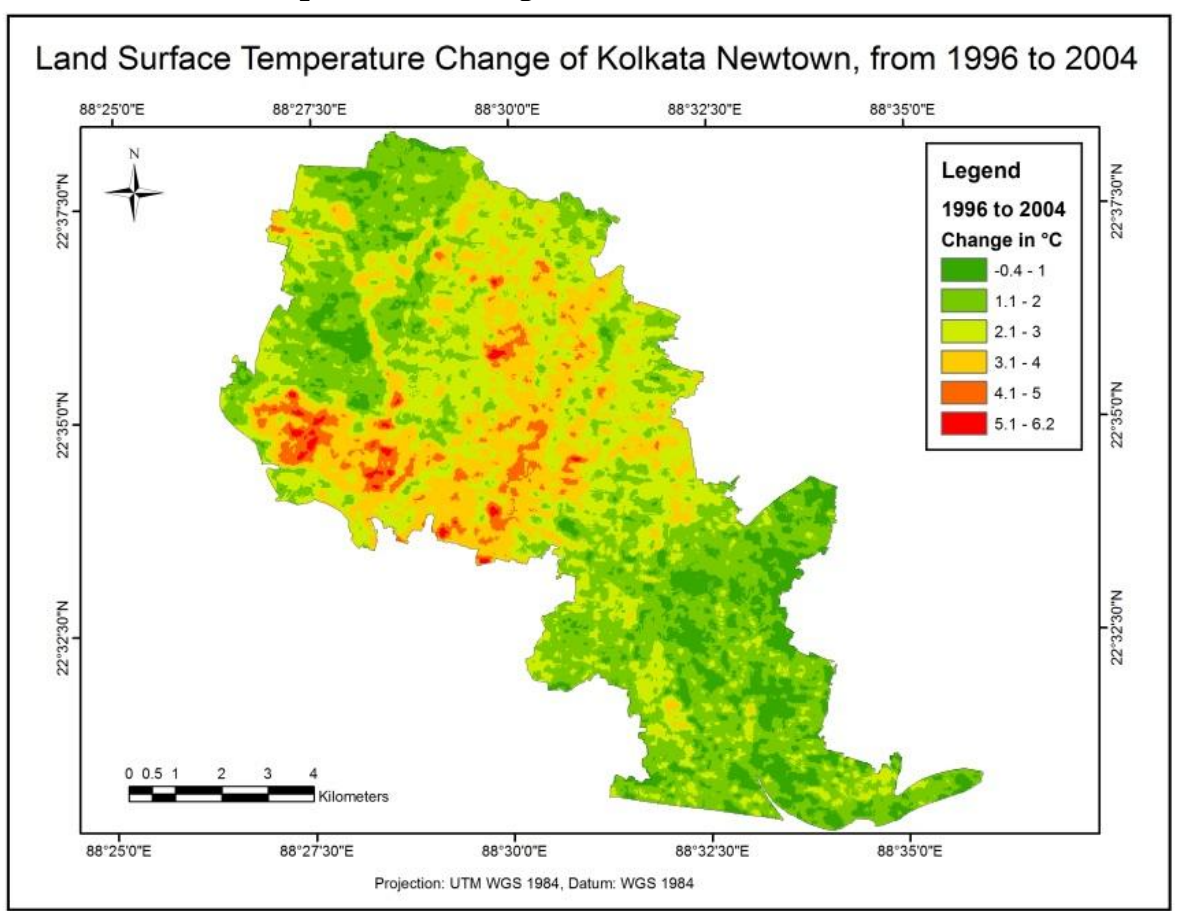

Map No. - 5: Change of LST from 2004 to 2014

Land Surface Temperature Change of Kolkata Newtown, 2004 to 2014

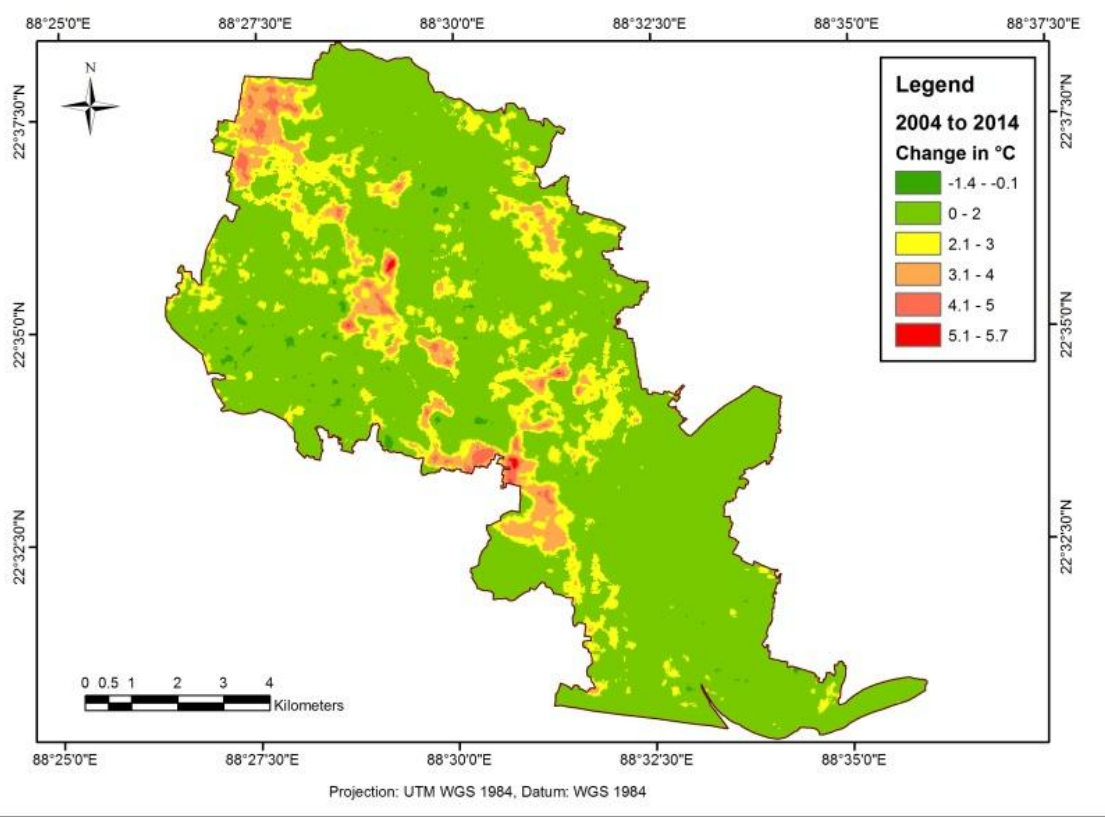


Map No. - 6: Change of LST from 1996 to to 2014

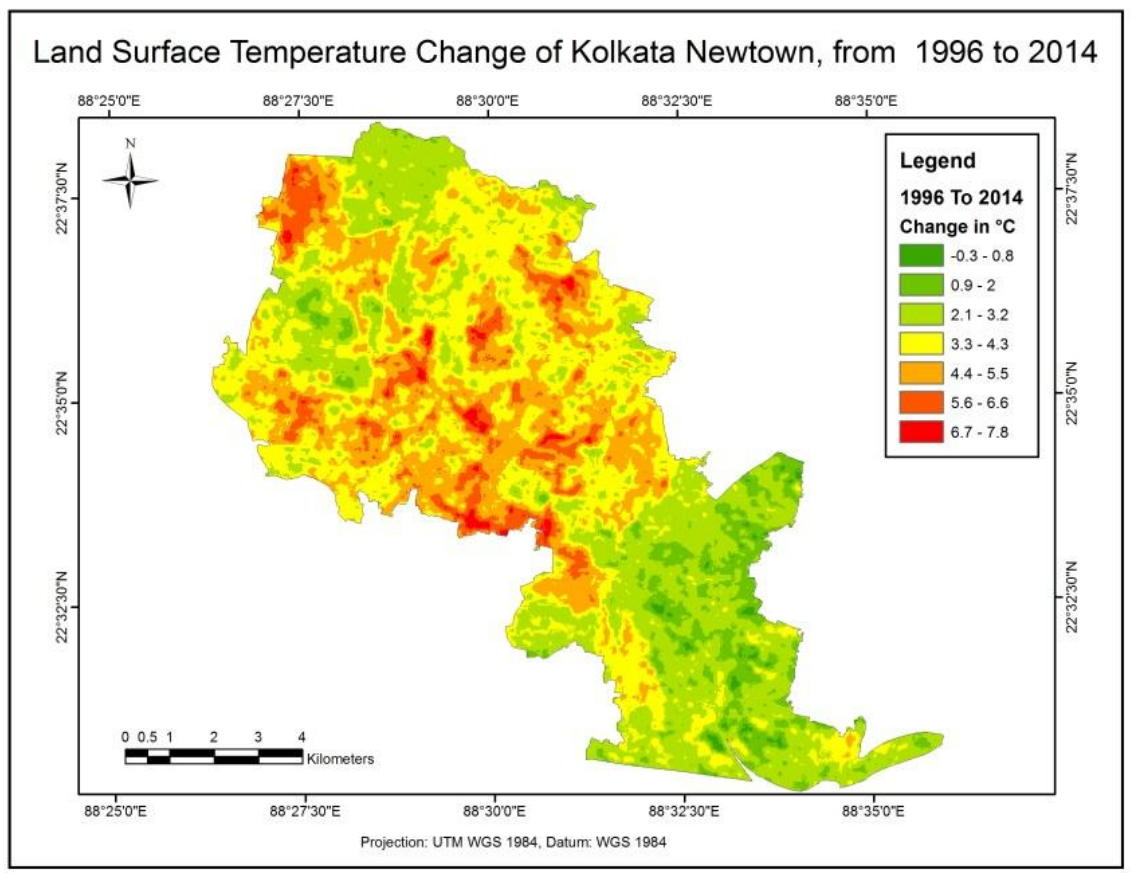

The change of LST from 1996 to 2004 was $-.04^{\circ} \mathrm{C}$ to $6.2^{\circ} \mathrm{C}$. It was $-1.4^{\circ} \mathrm{C}$ to $5.7^{\circ} \mathrm{C}$ from 2004 to 2014 . In the change map from 1996 to 2014 it is increased more than 1996 to 2004 and 2004 to 2014 map as cumulative effect. It became $-0.3^{\circ} \mathrm{C}$ to $7.8^{\circ} \mathrm{C}$. Such a change in LST is creating urban heat island like other city. The change of LST by $6^{\circ} \mathrm{C}$ and $7^{\circ} \mathrm{C}$ and location of urban heat island in 2014 are shown.

Table - 7: Changing pattern of Spatial Variation of LST (1996 to 2014)

\begin{tabular}{|l|l|l|}
\hline \multirow{2}{*}{ Time Period } & \multicolumn{3}{|l|}{ Spatial Variation of Temperature in ${ }^{\circ} \mathrm{C}$} \\
\cline { 2 - 3 } & Maximum & Minimum \\
\hline $1196-2004$ & 6.2 & -0.04 \\
\hline $2004-2014$ & 5.7 & -1.4 \\
\hline $1196-2014$ & 7.8 & -0.3 \\
\hline
\end{tabular}

Map No. - 7: Change of LST $6^{\circ} \mathrm{C} \& 7^{\circ} \mathrm{C}, 1996-2014$

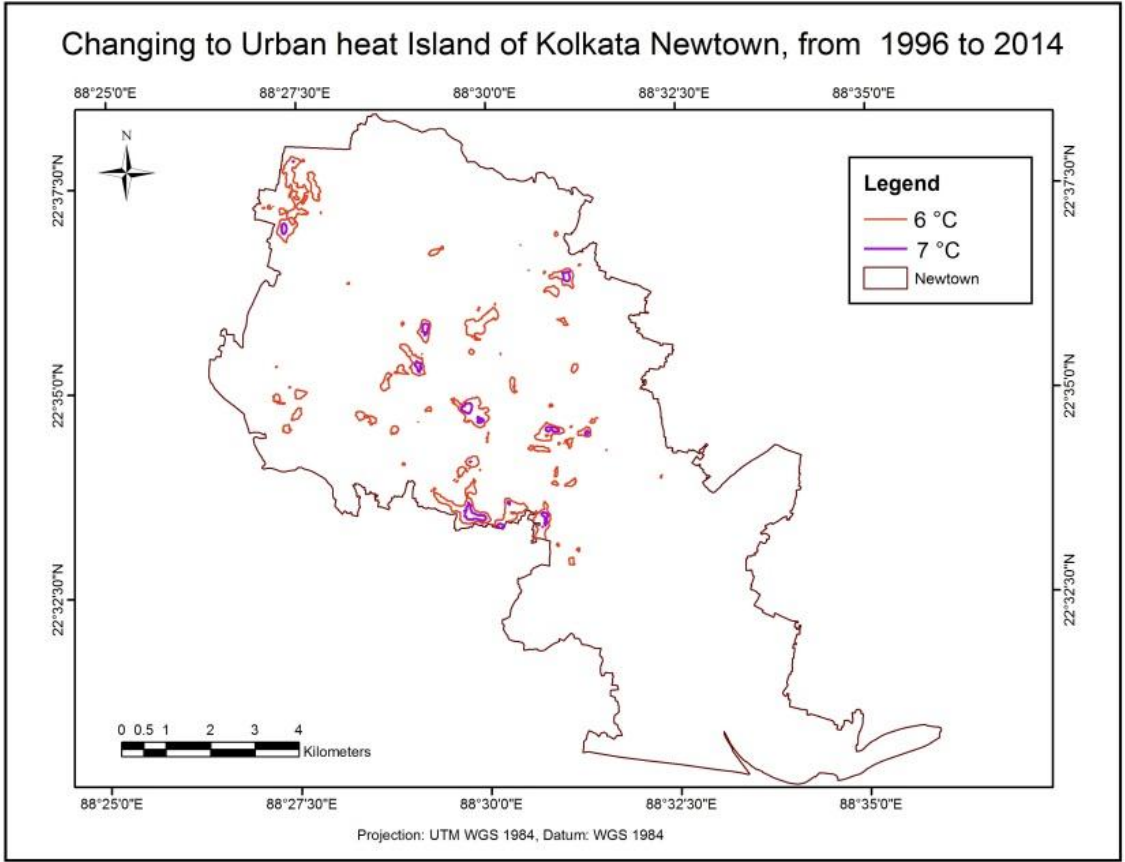


Map No. - 8: Urban Heat Island, 2014

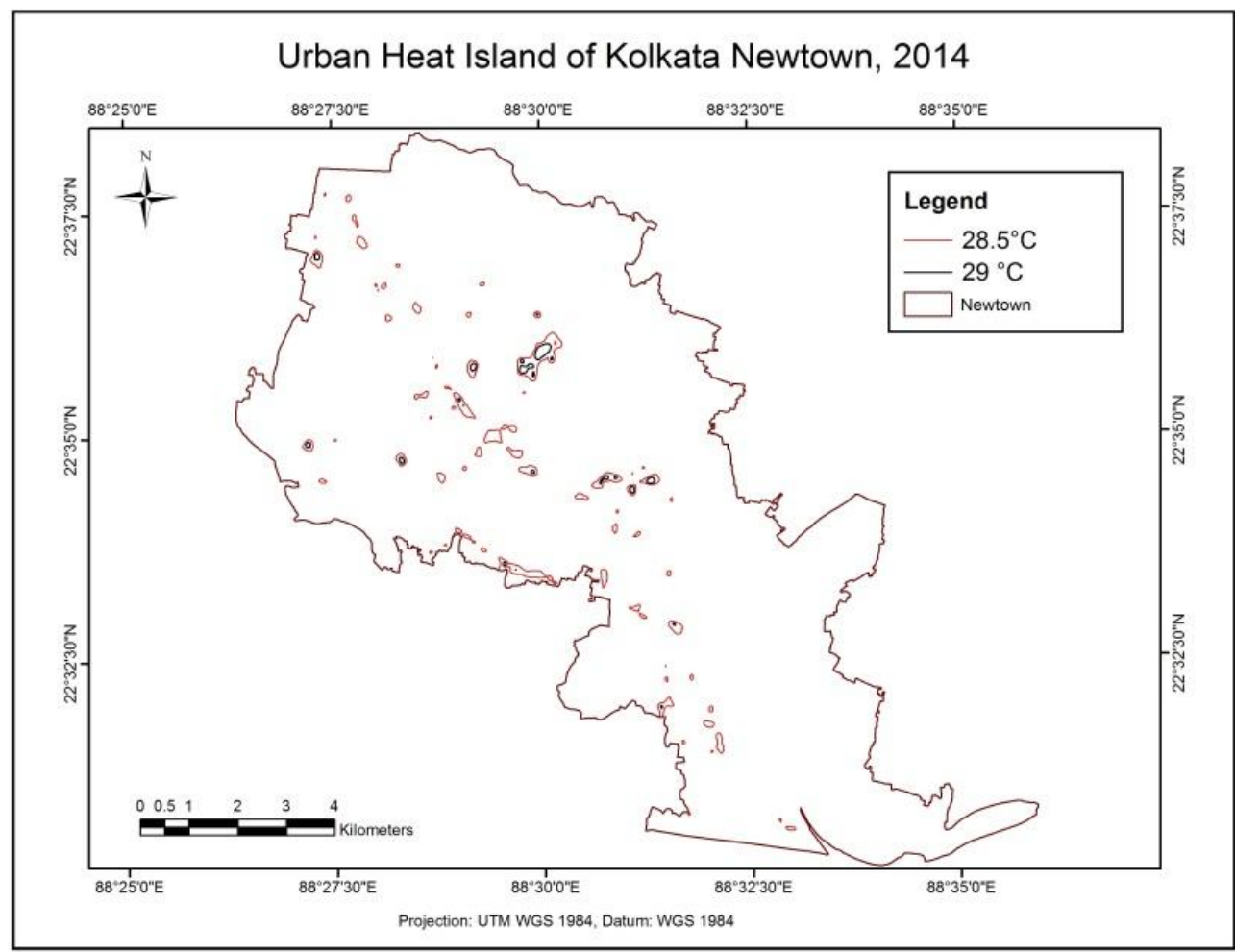

To know the distribution of LST profiles of LST are drawn (Fig - 2) which also shows that the built up area like roads, buildings are warmer than grassland, vegetation covered area and water bodies. Profiles lines are shown in high resolution Google Earth images of 25/10/2014 (as Nov, 2014 image is not available.) (Map No-9).

Map No. - 9: Falls Natural Colour Composite of Landsat 8, Nov, 2014 and profile lines

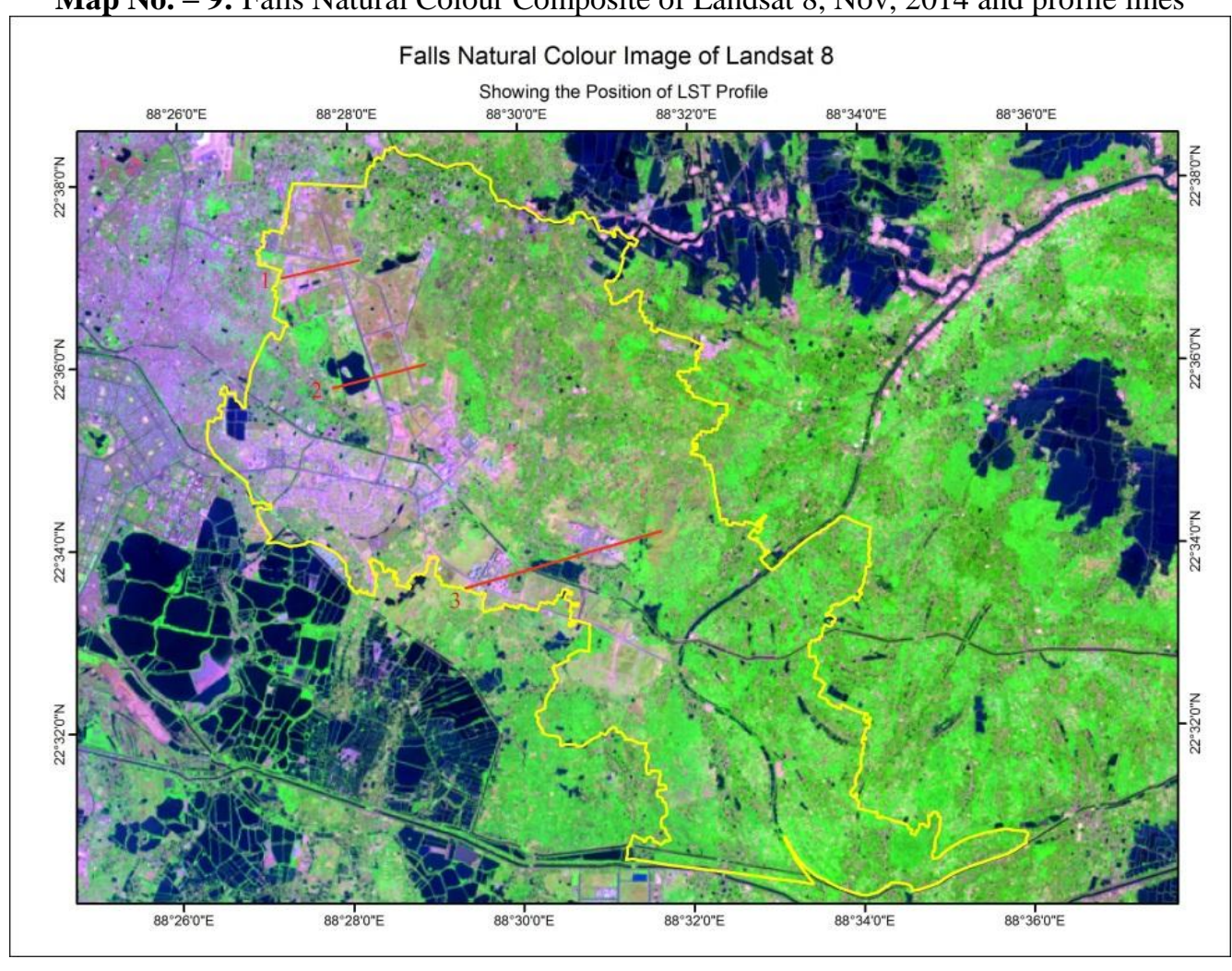


Fig-2: Selected LST profile and Google Earth Image, 2014
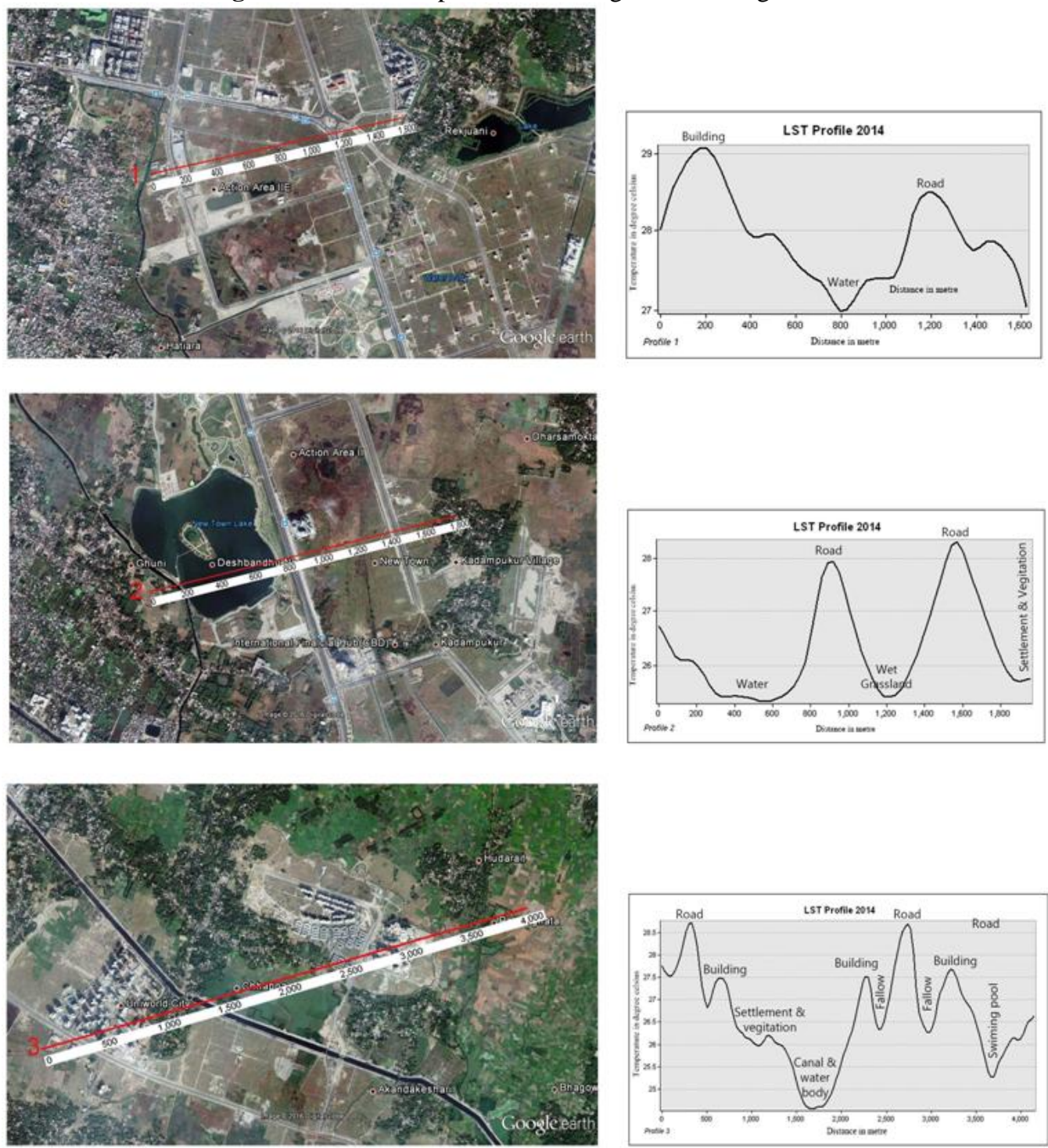

The profiles also show spatial irregularity of LST. It is understood that The LST on fallow is quite lower than built-up and the water bodies remain coolest of all. (Profile - 1, 2,3)

\section{CONCLUSION}

Analyzing all the maps and data, it is understood that development of Kolkata New Town is causing increase of Land Surface Temperature. Felling of tree, conversion of wetlands and agricultural land for building up the new town have adverse effects on micro-climate of the area, and several pockets of heat zones have sprout up. A prior attention is needed to address the micro-climate changes of the area for a sustainable city development.

\section{REFERENCES}

[1]. Almutairi. Menawer K, "Derivation of Urban Heat Island forLandsat-8 TIRS Riyadh City (KSA)." Journal of Geoscience and Environment Protection, 2015, 3, 18-23

[2]. http://dx.doi.org/10.4236/gep.2015.39003

[3]. Bhatti. Saad Saleem and Tripathi. Nitin Kumar, "Built-up area extraction using Landsat 8 OLI imagery", GIScience \& Remote Sensing, 2014, 51:4, 445-467

[4]. http://dx.doi.org/10.1080/15481603.2014.939539

[5]. Bouhennache R. et. al" Extraction of urban land features from TM Landsat image using the land features index and Tasseled cap transformation" Recent Advances on Electroscience and Computers, 142-147

[6]. Chakrabarty, Kakali et. al, "Land People and Power- an anthropological study of emerging new town, Rajarhat", 2015, Gyan Publication, pp - 15-23

[7]. Chen, X.-L.; Zhao, H.-M.; Li, P.-X.; Yin, Z.-Y. "Remote sensing image-based analysis of the relationship between urban heat island and land use/cover changes." Remote Sensing. Environ. 2006, 104, 133-146. 
[8]. F Yuan, ME Bauer "Comparison of Impervious Surface Area and Normalized Difference Vegetation Index as Indicators of Surface Urban Heat Island Effects in Landsat Imagery.”, Remote Sensing of Environment, 2007, 106(3), 375-386

[9]. Hasanlou. Mahdi and Mostofi. Nikrouz " Investigating Urban Heat Island Estimation and Relation between Various Land Cover Indices in Tehran City Using Landsat 8 Imagery", 1st International Conference on Remote Sensing, 22 Jun-5 July, 2015

[10]. Islam. Sk Majharul et.al, "Estimation of Land Surface Temperature of Chilika Lagoon Watershed and its Dependence on Terrain Properies", Indian Journal Of Geography And Environment,78-99

[11]. Landsat 8 data user hand book

[12]. Landsat 8 product user Guide.

[13]. http://landsat.usgs.gov/Landsat8_Using_Product.php

[14]. Latif, Md Shahid, "Land Surface Temperature Retrival of Landsat-8 Data Using Split Window Algorithm- A Case Study of Ranchi District", International Journal of Engineering Development and Research, 2014, Volume 2, Issue 4, p-1

[15]. Liu. Lin and Zhang. Yuanzhi, "Urban Heat Island Analysis Using the Landsat TM Data and ASTER Data: A Case Study in Hong Kong," Remote Sensing. 2011, 3, 1535-1552; doi:10.3390/rs3071535

[16]. Mallick. Javed et.al "Estimation of land surface temperature over Delhi using Landsat-7 ETM+", J. Ind. Geophys. Union ( July 2008 ) Vol.12, No.3, pp.131-140

[17]. Rhinane. Hassan et.al, "Contribution of Landsat TM Data for the Detection of Urban Heat Islands Areas Case of Casablanca” Journal of Geographic Information System, 2012, 4, 20-26, http://dx.doi.org/10.4236/jgis.2012.41003

[18]. Sadhu. Sujoy,'Identification of urban hot spots in relation to built-up surface and nature of buildings in the Kolkata Municipality Corporation (KMC) area," in Climate Change and Socio-Ecological Transformation, Today and Tomorrow Publisher, (2015), 451464

[19]. Sobrino. Jose' A et. Al, "Land surface temperature retrieval from LANDSAT TM 5"Elsevier, 2004, 1-7

[20]. Van de Griend. A.A.; Owe, M. "On the relationship between thermal emissivity and the normalized difference vegetation index for natural surfaces". Int. J. Remote Sens. 2003, 14, 1119-1131.

[21]. Zha, Y.; Gao, J.; Ni, S. "Use of normalized difference built-up index in automatically mapping urban areas from TM imagery." Int. J. Remote Sens. 2003, 24, 583-594. 